\title{
AGRICULTURE CATEGORY ADVANTAGES AND ECONOMIC STRUCTURES IN THE REGION OF WEST NUSA TENGGARA PROVINCE
}

\author{
Kategori Pertanian Unggulan dan Strukur Ekonomi Wilayah \\ di Provinsi Nusa Tenggara Barat
}

\author{
Muhamad Hirzan Hadi Muslim, Jamhari, Dwidjono Hadi Darwanto \\ Master of Agribussiness Management, Agriculture Faculty, Universitas Gadjah Mada \\ Jl. Flora, Bulaksumur, Kec.Depok, Kabupaten Sleman, \\ Daerah Istimewa Yogyakarta 55281 \\ hirzanmuslim@gmail.com
}

Diterima tanggal 10 April 2017 ; Disetujui tanggal 12 Juni 2017

\begin{abstract}
This research aims to identify [1] the highest agricultural category contribution in the West Nusa Tenggara province; [2] basic or non-basic category in current and future; [3] economic structure changes in the agricultural category; [4] classifying agricultural category. This research by a descriptive method. The data analysis by Location Quotient, Dynamic Location Quotient, Shift-Share and Klassen Typology. The results with the highest contribution to the West Nusa Tenggara GRDP is the agriculture category of $23.5 \%$. The highest contribution of an agricultural category to the agricultural category GRDP in West Nusa Tenggara is a Bima Regency of $46.8 \%$. Based on LQ analysis, forestry and logging categories by $2.41 \%$ and fisheries category by $1.16 \%$ are categorized as a base, and the agriculture category* (agriculture, farming, hunting and agricultural services) is non-base categories of $0.96 \%$. Based on the DLQ analysis, there is a repositioning structure in agriculture category* that Originally non-base $0.96 \%$ to a base $1.00 \%$, as for forestry and logging categories and fishery categories remain base. Based on the shift-share analysis, all categories are positive values, the highest category is agriculture category* 1,528,544,064,778.96 (million) influenced by provincial economic growth, industry mix and the influence of competitive advantage. Based on the Klassen Typology analysis, there are two classifications of agriculture category that is the prime classification (forestry and logging category and fishery category) and potential classification (agriculture category*).
\end{abstract}

Keywords: Agriculture Category, Base Category, GRDP, Klassen Typology, Shift-Share

\section{INTISARI}

Penelitian ini bertujuan untuk mengidentifikasi [1] kontribusi kategori pertanian wilayah tertinggi terhadap Provinsi Nusa Tenggara Barat; [2] kategori basis atau non-basis saat ini dan masa mendatang wilayah terpilih; [3] perubahan struktur ekonomi kategori pertanian wilayah terpilih; [4] mengklasifikasikan kategori pertanian wilayah terpilih di Provinsi Nusa Tenggara Barat. Penelitia ini menggunakan metode deskriptif. Analisis data menggunakan Location Quotient (LQ), Dynamic Location Quotient (DLQ), Shift-Share dan Tipologi Klassen. Hasil penelitian menunjukkan kategori dengan kontribusi tertinggi terhadap PDRB Nusa Tenggara Barat yaitu kategori pertanian sebesar 23.5\%. Kontribusi kategori pertanian tertinggi terhadap PDRB kategori pertanian Nusa Tenggara Bara 
adalah Kabupaten Bima sebesar 46.8\%. Berdasarkan analisis LQ, kategori kehutanan dan penebangan kayu sebesar $2.41 \%$ dan kategori perikanan senilai $1.16 \%$ merupakan kategori basis dan kategori pertanian*(pertanian, peternakan, perburuan dan jasa pertanian) merupakan kategori non-basis senilai 0.96\%. Berdasarkan analisis DLQ, terdapat reposisi struktur pada kategori pertanian* yaitu dari non-basis seniali $0.96 \%$ menjadi basis seniali $1.00 \%$, adapun kategori kehutanan dan penebangan kayu dan kategori perikanan tetap basis. Berdasarkan analisis shift-share, semua kategori bernilai positif dengan kategori tertinggi adalah kategori pertanian* sebesar Rp 1.528.544.064.778,96 (juta) yang dipengaruhi oleh pertumbuhan ekonomi provinsi, bauran industri Kabupaten Bima dan pengaruh keunggulan bersaing. Berdasarkan analisis tipologi klassen, terdapat dua klasifikasi kategori pertanian yaitu klasifikasi prima (kategori kehutanan dan penebangan kayu dan kategori perikanan) dan klasifikasi potensial (kategori pertanian*).

Kata Kunci: Kategori Basis, Kategori Pertanian, PDRB, Shift-Share, Tipologi Klassen

\section{INTRODUCTION}

Regional economic development with territorial economic development has a reciprocal relationship as regional development with the aim of improving the living standards and welfare of territory communities. Economic region or territory development is a process involving local governments and communities in managing existing resources and forming partnerships between local governments with private sector to create new jobs and stimulate the development of economic activities (Arsyad, 1999). The main objective of economic region/territory development is to create prosperity for all local communities. The Efforts in achieving these objectives, the government must formulate clearly related to prosperity or economic prosperity to be achieved, of course with the involvement of local communities because the community itself knows more which economic sector is very important to be improved, developed and maintained in accordance with the socioculture of the area (Ogari et al, 2014).

The Efforts in achieving region/ territory development are important for the government knowing the potential owned by the region or territory, such as; community economic conditions, natural resource potential, human resources, and infrastructure. Economic development can be measured by the value of its gross regional domestic product (GRDP). According to Widianingsih (2015), namely the growth and improvement of gross regional domestic product (GRDP) from year to year is an indicator of regional development success.

West Nusa Tenggara Province consists of ten districts or cities (West Lombok, Central Lombok, East Lombok, North Lombok, West Sumbawa, Sumbawa, Dompu, Bima, Mataram City and Bima City). Those are the regional that have 
the freedom to manage the economic potential and financial resources it has for the improvement of people's welfare. According to Kuncoro M. and Idris A. L. (2010), regional autonomy since 2001 has a positive impact on the level of economic growth and GRDP percapita. The era of regional autonomy and fiscal decentralization namely the local government is given authority in managing its financial resources to encourage the development process in each region to encourage the national development process.

The economy of West Nusa Tenggara Province is supported by seventeen business fields/categories (a new term used in GRDP with the base year of 2010 compiled based on business category/industry as a substitute for the sector term in the preparation of GRDP base year 2000) that can produce goods and services as contained in GRDP are: 1) Agriculture, Forestry, and Fisheries; 2) Mining and Quarrying; 3) Processing Industry; 4) Procurement of Electricity and Gas; 5) Water Supply, Waste Management, Waste and Recycling; 6) Construction; 7) Big and Retail Trading; Repair of Cars and Motorcycles; 8) Transportation and Warehousing; 9) Provision of Accommodation and Drinking; 10) Information and Communication; 11) Financial Services and Insurance; 12) Real Estate; 13) Company Services; 14) Mandatory Government, Defense and Social Security Administration; 15) Educational Services; 16) Health Services and Social Activities and 17) Other Services (BPS, 2016).

According to PBS (2016), GRDP of West Nusa Tenggara Province based on constant price in 2011-2015 average reaches Rp 73.130.305 (in million). Viewed by the trend, generally the number of West Nusa Tenggara Province GRDP from year to year continues to increase. Of the Seventeen categories in Nusa Tenggara Barat Province, the category with the highest value is the agriculture category with an average value of 17,046,225 (in million) and the lowest is electricity and gas procurement category with an

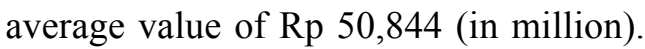
Based on the structure of GRDP with the preparation of the 2010 base year, the agriculture category consists of three categories including; a) agriculture category (agriculture, farming, hunting and agricultural services); b) forestry and logging categories and c) fishery categories, these categories constitute the constituent categories of the high values found in the agriculture category generally.

Regional economic growth an indicator that to used in measuring the level of people welfare in region's (Badrudin R., 2012). The Efforts of economic regional growth, the agriculture category is each one means that can be utilized optimally in an effort to prosper the community. The 
agriculture category is a base economic regional category (BPS, 2016). The majority of Indonesians lives in rural areas where most of their economic activities are in the agricultural category. The category of agriculture is the provision of local food ingredients and the absorption of labor, the source of raw material producers for industries and sources of foreign exchange.

According to Jhingan (2012), the effort to support the welfare of the community, agriculture category has several roles, which are: (1) as a means of fulfilling the needs or providers of food community, as a solution of the increasing needs of society accompanied by population growth more rapidly; (2) to meet the increasing demand of industrial products, causing the expansion of secondary category and tertiary category; (3) increasing foreign exchange for the import of capital goods for development through continuous export of agricultural products;

(4) as an incentive to increase village revenues mobilized by the government, and (5) as a means of improving the welfare of rural communities.

Based on the above description, it is more necessary to research about: [1] the contribution of the highest agricultural category in the West Nusa Tenggara province, which is applied to the next aim; [2] a base or non-basis category in the existing and future condition; [3] the changes of economic structure of territory agricultural category; [4] agricultural category selected classification by West Nusa Tenggara Province.

\section{METHODS}

This research was conducted at West Nusa Tenggara Province by using a descriptive method. The data used in this research are secondary data with time series data from gross regional domestic product (GRDP) at constant 2010 prices, according to business field from the period of 20112015 (five years). The data in this research by the Central Bureau of Statistics in West Nusa Tenggara Province. Data collected by library method approach (Library Research) and literature study of a book, journal or the result of other research which have been done.

Research data were analyzed by using Location Quotient (LQ), Dynamic Location Quotient (DLQ), Shift-share and Klassen Typology.

\section{Location Quotient (LQ)}

Location Quotient (LQ) is a method commonly used to determine leading sector of a region (Fattah S. and Rahman A. 2013, Endi R., et al. 2015, Sinaga D. 2015, Tian Z. 2013). LQ aims to know the position of agriculture category that is analyzed whether including the base or non-base by comparing the agricultural category character of the territory with the regional agricultural category. LQ can be formulated as follows: 


$$
\mathrm{LQ}=\frac{\frac{\mathrm{x}_{\mathrm{i}}}{P D R B}}{\frac{\mathrm{X}_{\mathrm{i}}}{P N B}}
$$

Description:

$\mathrm{x}_{\mathrm{i}} \quad$ : Value added of agriculture category $i$ in the territory

PDRB : Gross Regional Domestic Product of territory

$\mathrm{X}_{\mathrm{i}} \quad$ : Value added of agriculture category $i$ in the province

PNB : Gross National Product or GRDP Province

Criteria:

LQ $>1$ : The role of agricultural category $\mathrm{i}$ in territory is greater than the agriculture category $i$ in the province.

$\mathrm{LQ}<1 \quad$ : The role of agricultural category $i$ in the territory an smaller than the agricultural category $i$ in the province.

\section{Dynamic Location Quotient (DLQ)}

The DLQ analysis will be determined the basic agricultural category in the future. Mathematically DLQ can be formulated as follows (Oktavia, 2015):

$$
\mathrm{DLQ}=\left(\frac{1+\mathrm{g}_{\mathrm{ik}} / 1+\mathrm{g}_{\mathrm{k}}}{1+\mathrm{G}_{\mathrm{ip}} / 1+\mathrm{G}_{\mathrm{p}}}\right) \mathrm{t}
$$

Description:

DLQ : Growth rates index of agricultural category $i$ in the territory

$\mathrm{g}_{\mathrm{ik}} \quad$ : Average growth rate of agricultural category $\mathrm{i}$ in the territory $\mathrm{g}_{\mathrm{k}} \quad$ : Average growth rate of total agricultural category in the territory

$\mathrm{G}_{\mathrm{ip}} \quad$ : Average growth rate of agricultural category $i$ in the province

$\mathrm{G}_{\mathrm{p}}$ : Average total growth rate of agricultural category in the province

t : Timed analysis

Criteria:

DLQ $>1$ : The growth rate of agricultural category $i$ in the territory can be expected to base in the future.

DLQ $<1$ : The growth rate of agriculture category $\mathrm{i}$ in the territory cannot be expected to base in the future.

$\mathrm{DLQ}=1$ : The growth rate of agricultural category $\mathrm{i}$ in the territory against growth rate in comparable province.

\section{Shift-Share}

The Shift-share analysis is to determine the performance or productivity of the agricultural category $i$ in the territory compared with the region and can affect the growth in the amount of its output. According to Amalia F. (2012), shift-share is used to determine changes and the structure shift of a region's economy. Mathematically according to Soepomo (1993) the general form of shift-share analysis formulation and its components are: 


$$
D_{i k}=N_{i k}+M_{i k}+C_{i k}
$$

Description:

: Agriculture category in research

k : Variable agricultural category of territory researched

p : A variable of agriculture category Province

$\mathrm{D}_{\mathrm{ik}}$ : Changes of agricultural category i in the territory

$\mathrm{N}_{\mathrm{ik}}$ : The national growth of agricultural category $i$ in the territory

$\mathrm{M}_{\mathrm{ik}}$ : The agricultural category industry mix $i$ in the territory

$\mathrm{C}_{\mathrm{ik}}$ : Competitive advantage of agricultural category $\mathrm{i}$ in the territory

This research uses the variables of agriculture category and GRDP stated as (y), then:

a) The real impact of growth, agriculture category territory: $\left(D_{i k}=N_{i k}+M_{i k}+\right.$ $\mathrm{C}_{\mathrm{ik}}$ or $\mathrm{y}^{*}{ }_{\mathrm{ik}}-\mathrm{y}_{\mathrm{ik}}$ )

b) Influence agricultural category of territory on Province growth: $\left(\mathrm{N}_{\mathrm{ik}}=\right.$ $\left.\mathrm{y}_{\mathrm{ik}} \cdot \mathrm{r}_{\mathrm{p}}\right)$

c) Proportional shift or an influence mix of agriculture category: $(\mathrm{Mik}=\mathrm{yik}$ (rip - rp))

d) Influence of competitive advantage: $\left(\mathrm{C}_{\mathrm{ik}}=\mathrm{y}_{\mathrm{ik}}\left(\mathrm{r}_{\mathrm{ik}}-\mathrm{r}_{\mathrm{ip}}\right)\right.$

Description:

$\mathrm{y}_{\mathrm{ik}}$ : Contribution of agricultural category $\mathrm{i}$ in the territory
$\mathrm{Y}^{*}{ }_{\mathrm{ik}}$ : Contribution of agricultural category $\mathrm{i}$ in the territory end of year analysis

$r_{i k} \quad$ The growth rate of agricultural category $i$ in the territory

$r_{i p}:$ The growth rate of agricultural category $\mathrm{i}$ in Province

r : Average growth rate of agricultural category in Province

\section{Klassen Typology}

Klassen typology is to compare the level and growth rate territory of agricultural sector (Arsyad, 2010):

Table 1. Klassen Typology to Category

\begin{tabular}{|c|c|c|}
\hline \multirow{2}{*}{$\begin{array}{l}\text { Growth } \\
\text { Rate }\end{array}$} & \multicolumn{2}{|c|}{ Contribution } \\
\hline & $y_{i}>y_{n}$ & $y_{i}<y_{n}$ \\
\hline$r_{i}>r_{p}$ & $\begin{array}{l}\text { Category } \\
\text { Prima }\end{array}$ & Category Potential \\
\hline $\mathrm{r}_{\mathrm{i}}<\mathrm{r}_{\mathrm{p}}$ & $\begin{array}{c}\text { Category } \\
\text { Developed }\end{array}$ & $\begin{array}{c}\text { Category } \\
\text { Underdeveloped }\end{array}$ \\
\hline
\end{tabular}

Source: Arsyad (2010)

Description:

$r_{i}$ : The growth rate of agricultural category $i$ the territory

$r_{n}$ : The growth rate of agricultural category $i$ the province

$y_{i}$ : Contribution of agriculture category $i$ the territory

$y_{n}$ : Contribution of agriculture category $i$ the province 


\section{RESULTS AND DISCUSSION}

This section will describe the results/ answers to the intended purpose. The answer of the first objective (the contribution of the highest agricultural category in the province of West Nusa Tenggara) becomes the next analysis destination.

\section{The Highest Contribution Category of Territory to West Nusa Tenggara Province}

Economic growth in a territory reflects a change in economic structure in the region to be better and increased levels of community welfare. Economic growth can be an indicator of the region's economic development success. The economic growth can be measured by the increasing of adding value in the economic category that exist in the region as it is in the gross regional domestic product (GRDP).

West Nusa Tenggara Province consists of ten regencies/cities: 1) West Lombok District, 2) Central Lombok District, 3) East Lombok District, 4) Sumbawa District, 5) Dompu District, 6) Bima District, 7) West Sumbawa District, 8) North Lombok District, 9) Mataram City and 10) Bima Citi and consists of seventeen business fields/categories based on PDRB data. The formula of calculating this contribution is to divide the value of each category in each category of territory by the total value of the category in the region in the same year GRDP $_{\mathrm{i}}$ / Total GRDP $\mathrm{x}$
$100 \%)$. The data used in the calculation is the GRDP data of West Nusa Tenggara Province. The calculation results can be explained that the highest contribution each category of districts/cities as follows: West Lombok has agriculture category with a value of 22.0 percent, Central Lombok in the agriculture category that is 27.5 percent, East Lombok has in the agriculture category of 29.9 percent, Sumbawa has 40.2 percent in the agriculture category, Dompu in the agriculture category that is 41.2 percent, Bima in the agriculture category is 46.8 percent, West Sumbawa is reaching 83.4 percent in the category of mining and digging, North Lombok is approximately 37.0 percent the agriculture category, Mataram in the category of large and retail trade; car and motorcycle repairs worth 18.6 percent and Bima has the highest contribution to the big and retail trade category; car and motorcycle repairs worth 22.0 percent.

Generally, the total contribution of the category with the highest value in West Nusa Tenggara Province is the category of agriculture that is 26.9 percent and the lowest is the electricity and gas procurement category and the water supply, waste management, waste and recycling category of each 0.1 percent. The contribution of agriculture category in West Nusa Tenggara Province is supported by the contribution of Bima in the agriculture category is 46.8 percent, which is the 
Table 2. The Contribution of Each District/City Category in West Nusa Tenggara

\begin{tabular}{|c|c|c|c|c|c|c|c|c|c|c|c|c|c|c|c|c|c|}
\hline \multirow{2}{*}{$\begin{array}{l}\text { District/ } \\
\text { city }\end{array}$} & \multicolumn{17}{|c|}{ Business Field (\%) } \\
\hline & $1 *$ & $2 *$ & 3* & 4* & $5 *$ & $6^{*}$ & $7 *$ & 8* & 9* & $10^{*}$ & $11 *$ & $12 *$ & $13^{*}$ & $14 *$ & $15^{*}$ & $16^{*}$ & $17 *$ \\
\hline $\begin{array}{l}\text { West } \\
\text { Lombok }\end{array}$ & 22,0 & 6,8 & 5,2 & 0,1 & 0,1 & 13,3 & 12,5 & 9,7 & 6,4 & 2,4 & 2,6 & 3,2 & 0,1 & 6,2 & 4,8 & 2,0 & 2,5 \\
\hline $\begin{array}{l}\text { Central } \\
\text { Lombok }\end{array}$ & 27,5 & 4,1 & 6,3 & 0,1 & 0,1 & 12,4 & 10,7 & 15,7 & 1,0 & 1,7 & 1,9 & 3,4 & 0,1 & 5,8 & 4,5 & 2,5 & 2,3 \\
\hline $\begin{array}{l}\text { East } \\
\text { Lombok }\end{array}$ & 29,9 & 5,9 & 9,4 & 0,1 & 0,1 & 11,4 & 14,8 & 4,4 & 0,8 & 1,9 & 2,1 & 3,2 & 0,1 & 6,7 & 4,9 & 2,2 & 2,0 \\
\hline Sumbawa & 40,2 & 3,2 & 2,4 & 0,1 & 0,1 & 13,8 & 14,5 & 3,9 & 1,2 & 1,4 & 3,3 & 2,0 & 0,2 & 6,3 & 4,6 & 1,3 & 1,7 \\
\hline Dompu & 41,2 & 3,0 & 2,5 & 0,0 & 0,0 & 8,5 & 14,6 & 5,4 & 1,0 & 1,1 & 2,9 & 3,1 & 0,2 & 8,2 & 4,9 & 1,6 & 1,8 \\
\hline Bima & 46,8 & 3,0 & 2,4 & 0,1 & 0,1 & 6,3 & 14,8 & 7,5 & 0,3 & 1,4 & 2,7 & 2,5 & 0,1 & 6,4 & 3,4 & 1,0 & 1,3 \\
\hline $\begin{array}{l}\text { West } \\
\text { Sumbawa }\end{array}$ & 4,4 & 83,4 & 0,3 & 0,0 & 0,0 & 2,3 & 3,3 & 1,9 & 0,3 & 0,3 & 0,4 & 0,7 & 0,0 & 1,1 & 0,9 & 0,3 & 0,4 \\
\hline $\begin{array}{l}\text { North } \\
\text { Lombok }\end{array}$ & 37,0 & 3,8 & 1,5 & 0,1 & 0,1 & 9,0 & 13,2 & 5,5 & 5,4 & 2,0 & 2,5 & 4,1 & 0,3 & 6,1 & 5,5 & 1,7 & 2,2 \\
\hline $\begin{array}{l}\text { Mataram } \\
\text { City }\end{array}$ & 4,5 & 0,0 & 10,7 & 0,1 & 0,2 & 10,8 & 18,6 & 7,9 & 1,4 & 7,1 & 8,5 & 4,6 & 0,4 & 7,7 & 7,7 & 4,8 & 5,0 \\
\hline $\begin{array}{l}\text { Bima } \\
\text { City }\end{array}$ & 15,5 & 0,4 & 3,6 & 0,2 & 0,0 & 9,5 & 22,0 & 10,7 & 2,5 & 1,8 & 2,3 & 5,0 & 0,3 & 11,1 & 7,8 & 3,5 & 3,7 \\
\hline West & & & & & & & & & & & & & & & & & \\
\hline $\begin{array}{l}\text { Nusa } \\
\text { Tenggara }\end{array}$ & 26,9 & 11,4 & 4,4 & 0,1 & 0,1 & 9,7 & 13,9 & 7,3 & 2,0 & 2,1 & 2,9 & 3,2 & 0,2 & 6,6 & 4,9 & 2,1 & 2,3 \\
\hline
\end{tabular}

Source: GRDP Data West Nusa Tenggara Province by Year 2011-2015 Processed

Description of the Table 2 (Business Field):

1* Agriculture, Forestry, and Fisheries;

2* Mining and Quarrying;

3* Processing Industry;

4* Procurement of Electricity and Gas;

5* Water Supply, Waste Management, Waste and Recycling

6* Construction

7* Big and Retail Trading; Repair of Cars and Motorcycles

$8^{*}$ Transportation and Warehousing

9* Provision of Accommodation and Drinking

10* Information and Communication

$11^{*}$ Financial Services and Insurance

12* Real Estate

13* Company Services

14* Mandatory Government, Defense and Social Security Administration

$15^{*}$ Educational Services

16* Health Services and Social Activities

$17^{*}$ Other Services

highest contribution value of total GRDP of agricultural category in West Nusa Tenggara Province and the smallest is in West Sumbawa that is 4.4 percent. The contribution data of each district/city category in West Nusa Tenggara Province are presented in the table 2 .

Based on the advantages of the contribution of agriculture category in Bima, then the next aims of the agriculture category 
in Bima will be conducted a research/analysis to be known the agriculture component (category) in Bima is analyzed to find out the categorical basis or non-bases in the present and future by the analysis of Location Quotient (LQ) and Dynamic Location Quotient (DLQ), the economic structure of the agriculture category with Shift-share analysis and classifying categorical with Klassen Typology analysis. The results of the analysis with these methods, which is used as a foothold in formulating policies for regional development, to make regional development will be easier based on the specialization/ potential of the region. According to Hidayat and Supriharjo (2014), the development of strategic regional is the principal of economic growth that has stages and steps that must be formulated in reaching a goal, one of the stages can be formulated to develop a regional strategy is that by identifying the preeminent category owned by a region/territory.

\section{Base/non-base Agriculture Category}

Based on the contribution of agriculture category in Bima to West Nusa Tenggara Province give's an idea of the level of advantages (base) of the district.
Once known, Bima is the district with the highest agriculture category so further be specific to know the components. The component of the agricultural category in Bima is used Location Quotient (LQ) analysis to know the component is base/ non-base in the present. Data analysis results LQ is presented in the table 3.

The result of LQ analysis can be explained that the forestry and logging category and fishery category are the base category meaning that these two categories are categories that have dominant roles in Bima compared to their role in West Nusa Tenggara Province in other words the forestry and logging category and fishery category can meet the needs in Bima related to these categories and to meet the needs of other districts due to the surplus and to be a priority category in driving the economy for the development of Bima.

The second category of the base that has the highest base value is the forestry and logging category with an average of 2.41 percent and as for the fishery category with an average of 1.16 percent.

Activities that involving in forestry and logging category include: logging of various

Table 3. Bima Distric on Location Quotient

\begin{tabular}{lrrrrr}
\hline \multicolumn{1}{c}{ Economic Category } & \multicolumn{5}{c}{ LQ (\%) } \\
\cline { 2 - 6 } & 2011 & 2012 & 2013 & 2014 & 2015 \\
\hline Agriculture, Animal Husbandry, Hunting and & 0.96 & 0.96 & 0.95 & 0.96 & 0.96 \\
Agricultural Services & 2.41 & 2.41 & 2.41 & 2.41 & 2.39 \\
Forestry and Logging & 1.15 & 1.17 & 1.18 & 1.17 & 1.15 \\
Fishery &
\end{tabular}

Source: GRDP Data of NTB and Bima by Year 2011-2015 Processed 
types of timber, foliage, sap, and types of roots, including supporting forestry support services based on the reciprocal/contract system. The results of activities in the forestry category include logs (originating from jungle/cultivated forests), rattan, bamboo, firewood and other forest products as well as support forestry activities.

The agriculture category (agriculture, livestock, hunting and agricultural services) is a non-base category indicated by a contributory value of less than one $(<1)$ meaning that the productivity of category has not been able to run export activities to other districts/community in Bima itself but expect import from other regions. The non-basis of productivity of this category may be caused by the state of the territory that is still not possible to produce with the maximum or also may be due to low levels of public understanding to maximize the production category.

Terms of the base/non-base aspect in the future or whether there is a repositioning of category that was originally based on being non-base or vice versa that were originally non-base to base or does not reposition, be able to identify it, the agriculture category contained in Bima is analyzed by Dynamic Location Quotient (DLQ) analysis approach. This analysis compares the growth rate of existing category in Bima with the growth rate of category in West Nusa Tenggara Province. The function of this analysis is to predict the agricultural category in the future, whether to include base or non-base and provide information. There is a category reposition that emphasizes the growth rate.

The value of DLQ $>1$ means that the category in the existing agricultural category in Bima have the opportunity to become the base in the future or the growth rate of category in the agriculture category in Bima is faster than the growth rate of the same category in the Province of West Nusa Tenggara. If the value of DLQ $<1$ indicates that the category in the agriculture category cannot be expected to be the base category in the future, it means that the growth rate of categories in the agricultural category in Bima grows more slowly than the other cities/ districts with same category growth rate in West Nusa Tenggara Province. The results of the DLQ analysis are presented in the table 4.

Table 4. Bima District on Dynamic Location Quotient Analysis

\begin{tabular}{lrrrr}
\hline Economic category & \multicolumn{4}{c}{ DLQ (\%) } \\
\cline { 2 - 5 } & 2012 & 2013 & 2014 & 2015 \\
\hline Agriculture, Animal Husbandry, Hunting and Agricultural & 1,00 & 1,00 & 1,00 & 1,00 \\
Services & 1,00 & 1,00 & 1,00 & 0,99 \\
Forestry and Logging & 1,02 & 1,01 & 0,99 & 0,98 \\
Fishery
\end{tabular}

Source: GRDP Data of NTB and Bima by Year 2011-2015 Processed 
The results of the DLQ analysis in Table 4. can be explained that the three categories in the agriculture category can be expected to become the base in the future, meaning that the three categories in the existing agricultural category in Bima are growing (growth rate) faster than the growth rate of the same category at the level of West Nusa Tenggara Province. The results of the analysis also indicate that there is a category reposition that is in the agriculture category (agriculture, livestock, hunting and agricultural services) which was initially non-based by LQ analysis (the state of time analysis) and became the base in the future (forecast), meaning that the category can be expected to become a base in the future by optimizing the existing potential to increase its production to compete with other regions in the Province of West Nusa Tenggara.

The increase in agriculture category is caused by the activity of the population of Bima largely working in the agricultural category, especially food crops, because it is the staple food of Indonesian people in general and Bima in particular as well as the efforts in the framework of agricultural development and income increase of farmers which of course can Beneficial for the welfare of the local community as a whole. These efforts include intensification, extensification, diversification and rehabilitation of agricultural aspects. The increase is also supported by the extent of land in Bima, which is still dominated by agricultural land covering plantation land of 60,741 hectares and paddy fields of 42,962 hectares consisting mostly of irrigated land of 29,430 hectares and nonirrigated 13,532 hectares (BPS, 2016). Viewed from the aspect of the economic structure of Bima is also dominated by agriculture category with a role of 43.47 percent (BPS, 2016).

\section{The Changes Economic Structure of Agriculture Category}

The performance of the agriculture category in Bima and West Nusa Tenggara Province can be analyzed by using Shift-share analysis. The discussion on the performance of an agriculture category in generally to the change of economic structure (GRDP) during the analysis period (2011-2015) is influenced by growth components of Bima and West Nusa Tenggara $\left(\mathrm{N}_{\mathrm{ik}}\right)$, industry mix $\left(\mathrm{M}_{\mathrm{ik}}\right)$ and competitive advantage $\left(\mathrm{C}_{\mathrm{ik}}\right)$. The data for Shift-share analysis on Bima are presented in the table 5 .

Based on the results of Shift-share analysis, the category contained in the agriculture category in Bima is known that the economic growth of each category is positive, meaning that the real growth of the agriculture category has increased in all categories in agriculture category. Economic performance in agriculture category in Bima based on date of period of five years (2011-2015) amounted to $\mathrm{Rp}$ 
Table 5. Bima Distrik on Shift-share Analysis

\begin{tabular}{lrrrr}
\hline Economic Category & \multicolumn{1}{c}{$\mathrm{N}_{\mathrm{ib}}$ (juta) } & \multicolumn{1}{c}{$\mathrm{M}_{\mathrm{ib}}$ (juta) } & \multicolumn{1}{c}{$\mathrm{C}_{\mathrm{ib}}$ (juta) } & \multicolumn{1}{c}{$\mathrm{D}_{\mathrm{ib}}$ (juta) } \\
\hline $\begin{array}{l}\text { Agriculture, Animal } \\
\text { Husbandry, Hunting } \\
\text { and Agricultural }\end{array}$ & $1.528 .542 .567 .068,15$ & $3.955,69$ & $1.493 .755,13$ & $1.528 .544 .064 .778,96$ \\
\begin{tabular}{l} 
Services \\
\hline $\begin{array}{l}\text { Forestry and } \\
\text { Logging }\end{array}$
\end{tabular} & $20.878 .341 .750,62$ & $-53.063,38$ & $11.375,60$ & $20.878 .300 .062,83$ \\
\hline Fishery & $395.279 .440 .932,47$ & $27.347,59$ & $289.658,60$ & $395.279 .757 .938,66$ \\
\hline $\begin{array}{l}\text { Agriculture } \\
\text { Category }\end{array}$ & $1.944 .700 .349 .751,23$ & $-113.295,79$ & $1.773 .029,22$ & $1.944 .702 .009 .484,66$ \\
\hline
\end{tabular}

Source: GRDP Data of NTB and Bima by Year 2011-2015 Processed

1.944.702.009.484,66 (in million). The increase in the performance of agriculture category is supported by an increasing in the performance of all agricultural categories. The highest category performance in agriculture category which gives effect to the growth of the category is an agriculture category (agriculture, farming, hunting and agricultural services) that is $\mathrm{Rp}$ 1.528.544.064.778,96 (in million).

The growth, economic category in the agriculture category in the West Nusa Tenggara province be affects to a growth category in the category of agriculture in Bima. This can know about the values of $\mathrm{N}_{\mathrm{ik}}$ each category was positive. The magnitude of the economic growth influence of West Nusa Tenggara Province to agriculture category is $\mathrm{Rp}$ 1.944.700.349.751.23 (in million). The category that have the most dominant influence are the agriculture category (agriculture, farming, hunting and agricultural services) with the value of $\mathrm{N}_{\mathrm{ik}}$ Rp 1.528.542.567.068,15 (in million).

The forestry and logging category in Bima cannot specialize in increasing the region's revenues as indicated by the negative industry mix $\left(\mathrm{M}_{\mathrm{ik}}\right)$. Partially, the effect of industry mix $\left(\mathrm{M}_{\mathrm{ik}}\right)$ from each category indicates that the category witch cannot grow well is only the forestry and logging category indicated by a negative value of $\mathrm{Rp}-53.063,38$ (in million). The categories that can grow well are fishery category and agriculture category (agriculture, farming, hunting and agricultural services) with the value respectively $\operatorname{Rp} 27.347,59$ and $R p$ 3.955,69 (in million). Means that the activities of economic in the agriculture category in Bima are concentrated in fishery category and the agriculture category (agriculture, farming, hunting and agricultural services). The growth of fishery category and agriculture category (agriculture, farming, hunting and agricultural services) in West Nusa Tenggara Province is faster than the growth of fishery category and totally agriculture category (agriculture, farming, hunting and agricultural services) in West Nusa Tenggara Province.

Based on the value of competitive advantage $\left(\mathrm{C}_{\mathrm{ik}}\right)$, agriculture category 
(Agriculture, Animal Husbandry, Hunting and Agricultural Services), forestry and logging category and fishery category are categories that have a competitive advantage or higher competitiveness than the same category in other regions at the level West Nusa Tenggara Province. The growth rate of agriculture category in Bima is faster than the growth rate of agriculture category in West Nusa Tenggara Province. This is supported by the high growth rate in agriculture category (Agriculture, Livestock, Hunting and Agricultural Services). In line with the results of the DLQ analysis, the agriculture category can be the base and have competitiveness compared to the average value in West Nusa Tenggara Province. The competitiveness of category in the agriculture category is certainly supported by the condition of the natural resources territory and local government policies.

\section{Bima Distric on Classification Agriculture Category}

Classifies the category (agriculture) into four parts by using Klassen typology analysis, are: prime category, potential category, developing category and underdeveloped category. Klassen typology analysis can be illustrated by the results of LQ and DLQ analysis.

Klassen typology analysis was conducted in Bima with West Nusa Tenggara Province in agriculture category. The results of the Klassen typology analysis are presented in the table 6 .

Based on the value of Table 6. it can be simplified in the form of table to see the category of agriculture analyzed into the quadrant or class what with the provision that $y_{k}$ (the contribution of agriculture category in Bima), $y_{p}$ (the contribution of agriculture category in West Nusa Tenggara Province), $r_{k}$ (the growth rate of the agriculture category in Bima) and $r_{p}$ (the growth rate of agriculture category in West Nusa Tenggara Province). Data from the analysis of the Klassen typology in quadrant form is presented in the table 7.

Based on the analysis of Klassen typology, categories in the agriculture category in Bima classified into two categories namely; Prime category and potential category. Based on Table 7. it can be explained that the forestry and logging

Table 6. Bima Distric on Klassen Typology

\begin{tabular}{|c|c|c|c|c|}
\hline \multirow[t]{2}{*}{ Economic Category } & \multicolumn{2}{|c|}{$\begin{array}{l}\text { Contribution } \\
\text { Average (\%) }\end{array}$} & \multicolumn{2}{|c|}{$\begin{array}{l}\text { Growth Rate } \\
\text { Average (\%) }\end{array}$} \\
\hline & Bima & NTB & Bima & NTB \\
\hline $\begin{array}{l}\text { Agriculture, Animal Husbandry, Hunting and Agricultural } \\
\text { Services }\end{array}$ & 78,63 & 82,14 & 4,89 & 4,21 \\
\hline Forestry and Logging & 1,06 & 0,44 & 2,82 & 2,43 \\
\hline Fishery & 20,31 & 17,42 & 4,80 & 4,21 \\
\hline
\end{tabular}

Source: GRDP Data of NTB and Bima by Year 2011-2015 Processed 
Table 7. Bima Distric on Klassen Typology with Quadrant

\begin{tabular}{llccc}
\hline No. & \multicolumn{1}{c}{ Category } & $\begin{array}{c}\text { Contribution } \\
\text { Category }\end{array}$ & $\begin{array}{c}\text { Growth of } \\
\text { Category }\end{array}$ & Quadrant \\
\hline 1 & Agriculture, Animal Husbandry, Hunting and & $\mathrm{y}_{\mathrm{k}}<\mathrm{y}_{\mathrm{p}}$ & $\mathrm{r}_{\mathrm{k}}>\mathrm{r}_{\mathrm{p}}$ & $\mathrm{II}$ \\
& Agricultural Services & $\mathrm{y}_{\mathrm{k}}>\mathrm{y}_{\mathrm{p}}$ & $\mathrm{r}_{\mathrm{k}}>\mathrm{r}_{\mathrm{p}}$ & $\mathrm{I}$ \\
2 & Forestry and Logging & $\mathrm{y}_{\mathrm{k}}>\mathrm{y}_{\mathrm{p}}$ & $\mathrm{r}_{\mathrm{k}}>\mathrm{r}_{\mathrm{p}}$ & $\mathrm{I}$ \\
\hline
\end{tabular}

Source: GRDP Data of NTB and Bima by Year 2011-2015 Processed

category and fishery category are a prime category meaning that the contribution and growth rate of forestry and logging category and fisheries category in Bima is greater than the contribution and growth rate of similar category in West Nusa Tenggara, while the agriculture category (agriculture, livestock, hunting and agricultural services) is a category classified as quadrant II category (potential category) meaning that the category in Bima has smaller contribution than similar category contribution in West Nusa Tenggara Province but the growth rate of agriculture category (agriculture, livestock, hunting and agricultural services) in Bima is greater/faster than the growth rate of similar category in West Nusa Tenggara Province.

The judging from the results of the Klassen typology analysis, there is no category classified as developing and underdeveloped category, but there needs to be a step in anticipating the occurrence under the responsibility of local government, which is implemented into policy to develop category which still cannot become the prime category so that can have a greater positive impact on Bima.

\section{CONCLUSION AND SUGGESTION}

1. Based on the structure of the business field/GRDP category consisting of seventeen categories and agriculture category is the category with the highest contribution to GRDP of West Nusa Tenggara Province, which is 26.9 percent with the highest regency is Bima of 46.8 percent.

2. The category based on LQ analysis is forestry and logging category that is 2.41 percent and fishery category of 1.16 percent means that the category have a dominant role in Bima. The agriculture category (agriculture, livestock, hunting and agricultural services) does not a dominant role which is indicated by the category value of less than one (non-basis) of 0.96 percent. Based on the DLQ analysis, there are repositioned categories, which is agriculture category (agriculture, farming, hunting and agricultural services) which initially non-base is turned in to the base in the upcoming is 0.96 percent to 1.00 percent and the other two categories can still be expected to be the base. 
3. The structure of agriculture category in Bima is positive with highest value is agriculture category (agriculture, farming, hunting and agricultural services) which is $\mathrm{Rp}$ $1,528,544,064,788.96$ (in million) influenced by provincial economic growth, industry mix and competitive advantages with the positive of value.

4. There is a classification of agriculture category in Bima namely forestry and logging category and fishery category are a prime category and the agriculture category (agriculture, farming, hunting and agricultural services) is including in a potential category.

\section{REFERENCES}

Amalia F. 2012. 'Penentuan Sektor Unggulan Perekonomian Wilayah Kabupaten Bone Bolango Dengan Pendekatan Sektor Pembentuk PDRB' Jurnal Ekonomi. Vol. 11, No. 2, Oktober 2012.

Arsyad. 1999. Ekonomi Pembangunan. Edisi Keempat, BPFE. Yogyakarta.

Arsyad. 2010. Ekonomi Pembangunan. Edisi Kelima, UPP STIM YKPN. Yogyakarta.

Badrudin R. 2012. 'Pengembangan Ekonomi Lokal Kabupaten/ Kota Provinsi Daerah Istimewa Yogyakarta Menggunakan Tipologi Klassen Dan Location Quotient'. $J R M B$. Volume 7, No. 1, Juni 2012.

BPS. 2016. Nusa Tenggara Barat Dalam Angka. CV. Maharani.
Endi R., et al. 2015. 'Analisis Sektor Unggulan Dan Pengembangan Wilayah Di Kota Bandar Lampung 2000-2012'. Jurnal Ekonomi Pembangunan. Vol. 4, No. 1, April 2015.

Fattah S. and Rahman A. 2013. 'Analysis of Regional Economic Development in the Regency/Municipality at South Sulawesi Province In Indonesia'. Journal of Economics and Sustainable Development. Vol. 4, No.1, 2013.

Hidayat M. E. and Supriharjo R. 2014. 'Identifikasi Subkategori Unggulan Kecamatan di Kabupaten Lombok Tengah'. Jurnal Teknik Pomits. Vol. 3, No. 1 .

Jhingan. 2012. 'konomi Pembangunan dan Perencanaan. PT. Raja Grafindo Persada. Jakarta.

Kuncoro M. and Idris A. N. 2010. 'Mengapa Terjadi Growth without development di Provinsi Kalimantan Timur?'. Jurnal Ekonomi Pembangunan. Vololume 11, Nomor 2, Desember 2010, hlm. 172-190.

Ogari et al. 2014. 'Determine Leading Commodities of Agricultural In Ogan Komering Ulu Timur Regency' Jurnal Agro Ekonomi . „Vol. 25 / No. 2 December 2014.

Oktavia. 2015.Sektor Pertanian Unggulan di di Sumatera Selatan. Jurnal Agribisnis Vol.1 No.2 Juli 2015.

Sinaga D. 2015. 'Determination Analysis of Leading Economic Sector Against Forming Region GDP in Simalungun'. International journal of Innovative Research in Management. issue 4 Volume 3, 2015. 
Soepomo. 1993. 'Analisis Shift-share.

Perkembangan dan Penerapan'. Jurnal Ekonomi dan Bisnis Indonesia

Tian Z. 2013. 'Measuring Agglomeration Using the Standardized Location Quotient with a Bootstrap Method'.
Journal of Regional Analysis and Policy. Vol. 43 (2), 186-197, 2013.

Widianingsih W. 2015. 'Contribution of Agricultural Sector to Economic Growth in West Java Province'. Jurnal Agro Ekonomi. Vol. 26 / No. 2, Desember 2015. 